\title{
Hausa Language in Information and Communication Technology
}

By

\author{
S.A. ABDULMUMIN
}

Department of Nigerian and African Languages

Faculty of Arts, Ahmadu Bello University, Zaria

E-MAIL: saabdulmumin@yahoo.com

\begin{abstract}
Basically the main medium of expressing information and communication is through language. Human beings are generally endowed with the most effective means of information and communication i.e. language. The popular assumption is that Language is simply communication with words especially the human use of spoken or written words as a communication system. It is against this background that this study examined the use of Hausa Language in Information and Communication technology specifically as a medium of dissemination of information and or communication.
\end{abstract}

\section{Introduction}

In popular usage, the term information refers to facts and opinions provided and received during the course of daily life. One obtains information directly from other living beings, from mass media, from electronic data banks, and from all sorts of observable phenomena in the surrounding environment. A person using such facts and opinions generates more information, some of which is communicated to others during discourse, by instructions, in letters and documents, and through other media. Information organized according to some logical relationships is referred to as a body of knowledge, to be acquired by systematic exposure or study. Application of knowledge or skills yields expertise, and additional analytic or experiential insights are said to constitute instances of wisdom. Use of the term information is not restricted exclusively to its communication via nature language. Information is also registered and communicated through art and by facial expressions and gestures or by such other physical responses as shivering. Moreover, every living entity is endowed with information in the form of a genetic code. These information phenomena permeate the physical and mental world. Their variety has defied all attempts so far at a unified definition of information.

On the other hand, the subject of communication has concerned scholars since the time of ancient Greece. Until modern times, however, the topic was usually subsumed under other disciplines and taken for granted as a natural process inherent to each. In 1928 the English Literary critic and author I.A. Richards offers one of the first and in some ways still the best definitions of communication as a discrete aspect of human enterprise.

Communication takes place when one mind so acts upon its environment that another mind is influenced, and in that other mind and experience occurs which is like the experience of the first mind, and is caused in part by that experience.

Richard's (1928) definition is both general and rough, but its application to nearly all kinds of communication - including those between humans and animals (but excluding machines) - separated the contents of messages from the processes in human affairs by which these messages are transmitted. More recently, questions have been raised concerning the adequacy of 'any single definition of the term communication as it is currently employed. The American Psychiatrist and Scholar Jurgen Ruesch identifies 40 varieties of disciplinary approaches to the subject, including architectural, anthropological, psychological, political and many other interpretations of the apparently simple interaction described by Richards as quoted above. From the foregoing, it is obvious that information and communication may therefore be analyzed in varieties of approaches.

\section{Technology and Mass Communication}

Interest in communication has been stimulated by advances in science and technology which by their nature, have called attention of humans as communicating creatures. Among the first and most dramatic examples of the inventions resulting from technological ingenuity were the telegraph and telephone followed by others like wireless radio and telephoto devices. The development of popular newspapers and periodicals, broadcasting, motion pictures and television led to institutional and cultural innovations that permitted efficient and rapid communication between a few individuals and large populations. These media have been responsible for the rise and social power of the new phenomenon of mass communication.

The technology of modern mass communication 
results from the confluence of many types of inventions and discoveries, some of which the printing press, for instance, actually proceeded the Industrial Revolution. Technological ingenuity of the $19^{\text {th }}$ and $20^{\text {th }}$ centuries developed the newer means of mass communication, particularly broadcasting, without which the present near-global diffusion of printed words, pictures and sounds would have been impossible. The steam printing press, radio, motion pictures, television and sound recording - as well as systems of mass production and distribution were necessary before public communication in its present form might occur.

Technology was not, however, the only prerequisite for the development of mass communication in the West and also in Africa. A large public of literate citizens was necessary before giant publishing and Newspaper Empire could employ extant communications technology to satisfy widespread desire or needs for popular reading materials. Affluence and interest were, and are still prerequisites for the maintenance of the radio, television, cinema and recording industries as well as institutions that are most highly developed in wealthy, industrial nations. Even in countries in which public communication is employed largely for government propaganda, certain minimal economic, linguistic and educational standards must be achieved before this persuasion is accepted by the general public.

\section{Adaptability of Hausa Language in Information and Communication}

It is understood as an artifact of culture that spoken and written language generally may be considered as a universal channel of communication into which various societies dip differentially in order to expedite and specify the numerous points of contact between individuals.

Language remains, however, a partially understood phenomenon used to transact several types of discourse. Language has been classified on the basis of several criteria. One scheme established four categories on the basis of informative, dynamic, emotive and aesthetic functions. Since informative function of language is one of the components upon which the concept of this study is built, our attention here will particularly be paid to informative communication which deals largely with narrative aspects of meaning.

According to Vesterguard and Schroder (1994:16) in communication, language can perform a variety of function. We use language to express our emotions, to inform our interlocutors of facts of which they were not previously aware to influence people's actions or thoughts to talk about stories etc. It is also obvious that the informational function of language in general focuses on meaning.

For instance, when we convey to our interlocutor information which he/or she did not possess already, or when we ask for information, we use language informational. Thus, it is an undeniable fact that language if simply communication with words, especially the human use of spoken or written words as a communication system. It is in realization of some of these functions of language in general, that this study narrowed down its scope to examine the use of Hausa Language in particular and especially in the current discourse of information communication and development.

Jaggar (2001) informs us that, "Hausa is a major world language, spoken as a mother tongue by more than 30 million people in Northern Nigeria and Southern part of Niger (Republic), in addition to Diaspora communities of traders, muslim scholars and immigrants in urban areas of West Africa, such as Southern Nigeria, Ghana, Togo, and the Blue Nile province in the Sudan. It is also widely used as a second language (by millions of people) and has expanded rapidly as a lingua franca. Hausa is a member of the Chadic language family which together with Semitic, Cushitic, Omotic, Berber and Ancient Egyptian, is a coordinate branch of the Afroasiatic phylum".

Earlier on, before Jaggar's study of (2001), Furniss (1996) already reveals that:

"The Hausa Language is spoken by more than 50 million people in Nigeria, Niger, Northern Ghana, and in communities from Kaolock in Senegal to Khartoum in the Sudan.--- With some 400 Languages spoken in Nigeria, Hausa as a Lingua Franca, particularly in the north of Nigeria, brings together people from many different language backgrounds".

Similarly, Johnson (1997) also observes that "Hausa is the second most widely spoken language in Nigeria after English. It is spoken by millions in Africa South of the Sahara, especially in West Africa. It is also an international language used by many of the world's most reputable radio stations, including the BBC, VOA, Radio Moscoyv, Radio Beijing, Radio Deutsche Welle, and many others". 
Again, one of the latest information available in an Internet website says, "Hausa is spoken by an estimated 22 million native speakers, plus an additional million second language speakers. (http://www.hummet.ucla.edu/hummetlaflang/Hausa/ -language/bg.html).

In view of the foregoing reasons and evidences of use of Hausa, it is obvious that disseminating information and communication in Hausa Language should be attractive not only to Hausawa (Hausa speaking people) but to any who wishes to further develop the phenomenon of mass communication for information purposes.

Undoubtedly, the technological ingenuity of the $19^{\text {th }}$ and $20^{\text {th }}$ centuries developed the newer means of mass communication, particularly broadcasting, without which the present near-global diffusion of printed words, pictures and sounds would have been impossible. There is thus need to look at the use of Hausa in mobilisation and national development; as well as in globalisation.

\section{Hausa in Mobilisation for National and International Development}

The utility of Hausa Language in the present democratic dispensation to create awareness and to disseminate information on the unfolding government policies and activities need to be harnessed and reflected in the new era of information and communication technology(ICT). Junaidu (2000) remarked that "Hausa Language has for long been used for political activities and quasi-official functions to inform people in the northern part of the country". Therefore, in order to foster national development through an understanding of state policies and programmes the trends of Hausa Language use need to be further exploited.

This is very much in -line with the objectives of the 1986 language plan of Action for Africa that made the adoption and promotion of African languages for- official functions to have great advantages over the use of non-indigenous languages in democratizing process of formal education and involvement of the populatfons in the political, cultural and economic affairs of their country (OAU, 1986). Similarly, it is on noted that UNESCO will continue to foster and sustain the development of African Languages and culture.

\section{Hausa Language in Globalisation}

The much talked about globalisation is the product of scientific and technological innovations that understandably enables easy communication through information technology. It is this information technology that enables the communication of information or knowledge to any society in the world through computer network. Therefore, it is assumed that the world has been turned into a global village that information and communication can be accessed or passed at one's doorsteps. Croteau \& Hoynes (1987) add that communication happens instantaneously. Indeed, what now most concerns most observers is not the production and distribution of information but rather the glut of information at our fingertips.

Junaidu (2000) reports that Hausa studies have linked to trends of International Language Studies operating in different institutions in West Africa, Europe and America. Therefore, the fulfillment of the task of homogenization, and cross breed of knowledge in Hausa Studies as well as easy access globally is an imperative one. This is an effort that should involve tertiary institutions and language research outfits in Nigeria and in other parts of the world. Certain individuals and institutions in Europe, America and Africa have already started utilizing this technology. One of the pioneers in this regard is the Hausa Website created by a fourteen-year-old GhanaianFilipino in London. $\mathrm{He}$ is on site 3 and 4 at www.angle/fire.com./ab2./amadu/indec.html. (Weeklv Trust Vol. 3 No. 40. 2000:29). There are also several other Hausa websites today on the Internet.

Similarly, technology and mass communication have advanced to the extent that telephone communication services have been transformed and expanded from landline to mobile phones. There are of course, various companies that produce mobile phones, but NOKIA company for example has incorporated the use of Hausa Language, among other languages in its instructional guide booklet. This is an important strategy in persuading millions of their Hausa speaking consumers to acquire and use the product for communication.

\section{Hausa in Information Dissemination}

The use of Hausa as the Language of broadcasting by radio stations world over and the television stations in especially the predominantly Hausa speaking northern Nigeria, is indicative of the role of Hausa in information communication technology. These stations have utilized the Hausa Language, and products of Hausa Studies to reach millions of their Hausa audience in Africa Europe, America and Asia. The stations would continue to seek for Hausa language experts to man their services which require the development of mass communication skills in Hausa Language. 


\section{Hausa Language on the Internet}

The Internet is a conglomeration of computers that are connected via telephone cables and satellite links around the world. Nancy (1985) observes us that all the computers linked to the Internet can exchange information with each other. Once a computer is connected to the net, it is like a spider in the middle of a huge web. All the threads of the web can bring the required information from other computers. It is the biggest library of ideas in the world. The Internet has rapidly become one of the most ideological platforms created by mankind. It is like gargantuan shopping malls where one can purchase anything that human mind can create. Thus, it becomes an easy medium for spreading messages of all kinds, the good, bad and the ugly.

Interest on Hausa language on the internet manifests itself at the beginning of the year 2000. For example, one of the earliest reviews on Hausa culture and Language was by Abdullah (2000). He observe that "sense" and no. nonsense" being said there (on the Internet) about the Hausa people. In the same vain the Weekly Trust Newspaper, of December 29, - January 4, 2001, compiled a list of forty-three (43) websites on Hausa Language and articles on Hausa Language. This shows that there is no denying the fact that today there are several websites on Hausa Language, Literature and culture, mostly dedicated at spreading the gospel of Hausa in the current era of information communication technology development.

Guibi (2006) reports, that the role of internet in the growth and development of communication worldwide is well-documented in literature. The introduction of Internet has, and is, still playing a vital role in the day-to-day activities carried out by individuals and corporate organization, through languages. From Guibi's research report, two categories of Internet sites are identified viz: (a) are sites which mostly consist of views and opinions on existing Hausa material culture and literature, e.g. www.dandali.com and www.gamji.com. and (b), are Internet sites which are "more scholarly, drawing attention to aspects of Hausa culture either through research or

discussion form e.g. www.hummet.ucla.edu/hamnet./afland/hausal

indexframe.html. created by Professor Russel Schu of UCLA, USA. However, it is imperative to note that "the most popular Hausa website is www.bbchausa.com". (Guibi, 2006). Besides, the popular Federal Radio Nigeria Kaduna (FRCN) Hausa service is on the Internet, under a website as $w w w$.radionigeria.net. It is expected that sister states ratiod stations would follow suite in no distance period. Similarly, the famous Hausa Language
Newspaper Gaskiya Tafi Kwabo which is being published since 1039 is now online with website www.nigeriannews.com . In addition, the Hausa Newspaper - Aminiya is also on the Internet with a website www.dailvtrust.com . there is also the Hausa newspaper Leadership Hausa with a website www.leadershipnigeria.com.

\section{Concluding Remarks}

This study has attempted to show the use of Hausa Language in information and communication technology. More importantly, it concentrated on the utilization of Hausa Language as a medium of information, and communication in the new era of technology and mass communication with the view to showing that in information and communication the object of study is text, and text, which is a product of language, communicates meaning. Consequently, therefore, in communication, language is used informationally. 


\section{References}

Abdallah, U.A. (2000) "Hausa Language and Culture on the Internet in Weekly Trust No. 29, November 17 - 23, 2000.

Abdulmumin, S.A. (2003) Communication and Language. An Unpublished Research Report.

Bhatia, V.K. (1993) Analysing Genre: Language Use in Professional Settings. London: Longman Group, UK Ltd.

Bittner, J.R. (1980) Mass Communication: An Introduction New Jersey:

Prentice - Hall, Inc.

Croteau, D. and Hoynes, W. (1997) Media/Society Industries Images and Audiences. London: Pine Forge Press.

Communication (2008) Encyclopedia Britannica. Encyclopedia Britannica 2007 Ultimate Reference Suite. Chicago Encyclopedia Britannica.

Furniss, G. (1996) Poetry, Prose and Popular Culture in Hausa. Edinburgh: Edinburgh University Press.

Guibi, I.I. (2006). Modern Information Technology: An Assessment of Hausa on Internet. M. A.
African Language (Hausa) Thesis at D.N.A.L. ABU Zaria.

Information Processing. (2008) Encyclopedia Britannica. Encyclopedia Britannica

Ultimate Reference Suite. Chicago: Encyclopedia Britannica.

Jaggar, P.J. (2001) Hausa: Amsterdam/Philadephia: John Benjamins Publishing Company.

Johnson, D. (1997) "Culture and Art in Hausa Video Films" in Nigerian Video Films (ed.) Jonathan Haynes (1997), Ibadan: Kraft Books Limited.

Junaidu, I. (2000) "Hausa Studies Challenges and Prospects" A paper presented at conference on the Prospects Languages, Literature and Language Education in the New Millennium. Ottolijanikin, Lagos.

Nancy, C. (1985) The Internet Tool Kit. Singapore: Technical Publications Pte, Continental Press Pte Limited.

Website:

$\mathrm{htt} / /$ www.humme.ucla.edu/hummet/aflang/hausa/1 anguage/bag. html. 